\title{
MANAJEMEN STRATEGIS PEMERINTAH DAERAH DALAM PENGELOLAAN ASET TANAH DAN BANGUNAN KABUPATEN KOTAWARINGIN TIMUR PROVINSI KALIMANTAN TENGAH
}

\author{
Oleh \\ Sholly Salam Sitompul ${ }^{1}$, \\ Sadu Wasistiono ${ }^{2}$, Fernandes Simangunsong ${ }^{3}$ \\ 1) Institut Pemerintahan Dalam Negeri \\ Program Magister Terapan Studi Pemerintahan Daerah Institut Pemerintahan Dalam Negeri \\ sholly_sss@yahoo.co.id \\ ${ }^{2,3)}$ Institut Pemerintahan Dalam Negeri
}

\begin{abstract}
REGIONAL GOVERNMENT STRATEGIC MANAGEMENT IN THE MANAGEMENT OF LAND AND BUILDING ASSETS. IN EAST KOTAWARINGIN DISTRICT CENTRAL KALIMANTAN PROVINCE

The focus of this research is to explore, collect, process and analyze the management of land 1 and building assets in East Kotawaringin Regency, Central Kalimantan Province. The factors that influence and determine the strategic management concept that should be carried out to improve the management of land and building assets. The research uses theory by Doli D. Siregar related to the implementation of asset management as well as supporting and inhibiting factors. Then Hunger and Wheelen's theory is used to determine strategic management. This research uses qualitative methods with a descriptive approach. In collecting data, researchers conducted interviews, documentation, observations, focus group discussions and data triangulation on the strategic management of local governments in managing land and building assets in East Kotawaringin Regency, Central Kalimantan Province.

The results showed that the management of land and building assets has not all been addressed. Even though the BPK's opinion assessment is good, it still needs serious attention to the management of land and building assets. The influencing factors consist of supporting and inhibiting factors which are then determined by strategic management which should be carried out for success based on Hunger and Wheelen's theory, strategic management is obtained, among others: the realization of a good OPD asset report, the realization of synergy between local government agencies in the preparation and implementation $A P B D$, strengthening reform efforts to increase public trust, improving information systems, creating a professional work system, realizing the administration of regional assets in accordance with regulations, realizing increasingly quality regional asset management.
\end{abstract}

Keywords: land and building assets, improved asset management, strategic management.

\section{AbSTRAK}

Gokus penelitian ini adalah untuk menggali, mengumpulkan, mengolah dan menganalisis
pengelolaan aset tanah dan bangunan Kabupaten Kotawaringin Timur Provinsi Kalimantan 
Tengah. Faktor-faktor yang memengaruhi serta menentukan konsep manajemen strategis yang sebaiknya dilakukan untuk peningkatan pengelolaan aset tanah dan bangunan. Penelitian menggunakan teori oleh Doli D. Siregar terkait pelaksanaan pengelolaan aset serta faktor pendukung dan faktor penghambat. Kemudian teori Hunger dan Wheelen digunakan untuk menentukan manajemen strategis. Penelitian ini menggunakan metode kualitatif dengan pendekatan deskriptif. Dalam mengumpulkan data, peneliti melakukan wawancara, dokumentasi, observasi, focus group discussion dan triangulasi data tentang manajemen strategis pemerintah daerah dalam pengelolaan aset tanah dan bangunan Kabupaten Kotawaringin Timur Provinsi Kalimantan Tengah.

Hasil penelitian menunjukkan bahwa pengelolaan aset tanah dan bangunan belum semuanya dibenahi. Walaupun penilaian opini dari BPK sudah baik namun masih perlu pengelolaan aset tanah dan bangunan diperhatikan dengan sungguh-sungguh. Faktor-faktor yang memengaruhi terdiri dari faktor pendukung dan faktor penghambat yang kemudian ditentukan manajemen strategis yang sebaiknya dilakukan untuk keberhasilan berdasarkan teori Hunger dan Wheelen didapatkan manajemen strategis antara lain: terwujudnya laporan aset OPD yang baik, terwujudnya sinergi antar instansi pemerintah daerah dalam penyusunan dan pelaksanaan APBD, penguatan upaya reformasi untuk meningkatkan kepercayaan publik, peningkatan sistem informasi, terwujudnya sistem kerja yang profesional, terwujudnya penatausahaan aset daerah yang sesuai aturan, mewujudkan manajemen aset daerah yang semakin berkualitas.

Kata kunci: aset tanah dan bangunan, peningkatan pengelolaan aset, manajemen strategis

\section{PENDAHULUAN}

$\mathrm{P}$ emerintah Daerah Kabupaten Kotawaringin Timur telah menerapkan manajemen aset dalam pengelolaan aset daerah sehingga pada Laporan Keuangan Daerah tahun 2016 dan 2017 mendapat opini WTP (Wajar Tanpa Pengecualian) yang merupakan penilaian tertinggi yang diberikan oleh BPK (Badan Pemeriksa Keuangan). Meskipun pada akhirnya secara berturut-turut Laporan Pengelolaan Keuangan Pemerintah Daerah Kabupaten Kotawaringin Timur tahun 2016 dan 2017 mendapat opini WTP (Wajar Tanpa Pengecualian) terdapat permasalahan yang harus ditindaklanjuti berdasarkan catatancatatan dari Badan Pemeriksaan Keuangan (BPK). Laporan Hasil Pemeriksaan Tahun 2017 untuk pembenahan lebih lanjut di beberapa OPD dalam KIB tidak rinci dan tidak informatf.
Terdapat bangunan-bangunan lama di Kabupaten Kotawaringin Timur yang tidak terpakai menjadi terbengkalai sehingga menjadi aset yang idle, under utilize dan tidak jelas pemanfaatannya yang saat ini sedang menjadi sorotan adalah aset daerah berupa Pasar Mentaya, Gedung Olahraga, dan Balai Latihan Pelajar yang dibiarkan terbengkalai sehingga tidak dapat dimanfaatkan secara baik. Diperlukan adanya upaya nyata yang sistematis dan menyeluruh dalam pengelolaan aset yang kondisinya idle penyebab inefisiensi bagi pemerintah daerah yang membuat biaya operasional dan pemeliharaan yang cukup besar. Seiring dengan perkembangan manajemen aset yang dinamis, inisiatif dan strategis.

\section{Menurut Siregar (2014: 518)} berpendapat bahwa: "Manajemen aset sendiri dapat dibagi dalam lima tahapan kerja, yaitu inventarisasi aset, legal audit, penilaian aset, optimalisasi aset dan pengawasan dan pengendalian." 
Tabel 1 Persentase Aset Tanah dan Bangunan belum teridentifikasi berdasarkan rekapitulasi KIB A dan C Kabupaten Kotawaringin Timur tahun 2017 dan 2018

\begin{tabular}{|c|c|c|c|c|c|}
\hline KIB & Tahun & Uraian & $\begin{array}{c}\text { Jumlah } \\
\text { Keseluruhan } \\
\text { Aset }\end{array}$ & $\begin{array}{l}\text { Jumlah } \\
\text { Aset belum } \\
\text { Teridentifikasi }\end{array}$ & $\begin{array}{c}\text { Persentase } \\
(\%)\end{array}$ \\
\hline \multirow{3}{*}{ A } & \multirow{3}{*}{2017} & Luasan $\left(\mathrm{m}^{2}\right)$ & 1.837 & 160 & $8,71 \%$ \\
\hline & & Lokasi & 1.837 & 36 & $1,96 \%$ \\
\hline & & Sertifikasi & 1.837 & 1.784 & $97,11 \%$ \\
\hline \multirow{3}{*}{ A } & \multirow{3}{*}{2018} & Luasan $\left(\mathrm{m}^{2}\right)$ & 2.220 & 160 & $7,21 \%$ \\
\hline & & Lokasi & 2.220 & 37 & $1,67 \%$ \\
\hline & & Sertifikasi & 2.220 & 1.750 & $78,83 \%$ \\
\hline \multirow{3}{*}{$\mathrm{C}$} & \multirow{3}{*}{2017} & Luasan Lantai $\left(\mathrm{m}^{2}\right)$ & 3961 & 1.745 & $44,05 \%$ \\
\hline & & Lokasi & 3.961 & 638 & $16,11 \%$ \\
\hline & & Dokumen & 3.961 & 2.497 & $63,04 \%$ \\
\hline \multirow{3}{*}{$\mathrm{C}$} & \multirow{3}{*}{2018} & Luasan Lantai $\left(\mathrm{m}^{2}\right)$ & 4.206 & 1.777 & $42,25 \%$ \\
\hline & & Lokasi & 4.206 & 610 & $14,50 \%$ \\
\hline & & Dokumen & 4.206 & 2.391 & $56,85 \%$ \\
\hline
\end{tabular}

Sumber: BPKAD Kotawaringin Timur tahun 2017 dan 2018

\section{METODE PENELITIAN}

Dalam hal ini penulis menggunakan penelitian kualitatif dengan metode penelitian deskriptif untuk mendalami dan menjelaskan manajemen strategis pemerintah daerah dalam pengelolaan aset tanah dan bangunan Kabupaten Kotawaringin Timur Provinsi Kalimantan Tengah. Selanjutnya analisis data ini akan dilakukan secara deduktif induktif (logico hypothetico deductive). Kemudian Penelitian ini dirumuskan dengan teori atau konsep yang tepat tanpa menggunakan hipotesis.

Teori dan konsep yang akan dipakai atau diujikan melalui teori Manajemen Strategis oleh J. David Hunger dan Thomas L. Wheelen (2003) yang mana dalam manajemen strategis tersebut akan dianalasis melalui beberapa indikator, yakni (1) Pengamatan lingkungan (2) Perumusan strategi (3) Implementasi strategi (4) Evaluasi dan pengendalian.

\section{HASIL PENELITIAN DAN PEMBAHASAN}

\section{Pelaksanaan Pengelolaan Aset}

\section{- Inventarisasi Aset}

Masing-masing OPD memiliki pengurus barang yang berkoordinasi dengan bidang aset di BPKAD untuk melaporkan riwayat penambahan dan pengurangan aset yang akan diinput ke dalam sistem Informasi Barang Milik Daerah. Kemudian daripada itu pemerintah daerah melalui BPKAD harus melakukan pencocokan kesamaan data barang milik daerah seluruh OPD. Tentunya dilaksanakan pencocokan data aset tetap dalam Simda barang milik daerah pada tiaptiap perangkat daerah dengan database Simda barang milik daerah khususnya aset tanah dan bangunan. Adapun saran dari penulis untuk pemerintah daerah melalui Badan Pengelolaan Keuangan dan Aset Daerah agar terjalin komunikasi yang intensif dengan aplikasi Zoom. "Zoom adalah sebuah layanan konferensi video berbasis cloud computing. 


\section{- Legal Audit}

Terobosan yang dilakukan Pemerintah Daerah Kabupaten Kotawaringin Timur untuk memecahkan permasalahan legal yang terkait dengan penguasaan pengalihan aset tanah dan bangunan dengan membuat kerja sama MOU pemerintah daerah melalui BPKAD dan BPN. Kerja sama MOU ini dapat mencegah berbagai permasalahan aset mulai dari yang sering ditemui antara lain status hak penguasaan yang lemah, aset dikuasai pihak lain, pemindahtanganan aset yang tidak termonitor, penyerobotan pengambilalihan atau klaim dari pihak lain dan lain-lain.

\section{- Penilaian Aset}

Pelaksanaan penilaian aset tanah pada Pemerintah Daerah Kabupaten Kotawaringin Timur bekerja sama membentuk tim OPD terkait dengan BPN (Badan Pertanahan Nasional) yang bertugas di satuan tugas (Satgas) A yaitu pengukuran dan Satgas B yaitu yuridis. Masing-masing Satgas memiliki fungsi berbeda. Tugas Satgas A berkaitan dengan informasi fisik bidang tanah yaitu pengukuran. Tugas Satgas B berkaitan dengan aspek informasi yuridis bidang tanah. Setelah data terkumpul, maka akan langsung diserahkan ke OPD yang memerlukan penilaian tanah yang diketahui oleh Badan Pengelola Keuangan dan Aset Daerah.

\section{- Optimalisasi Aset}

Pemerintah Daerah Kabupaten Kotawaringin Timur harus melakukan review daftar aset potensial dengan analisis highest and best use aset potensial kemudian merekomendasi langkah lanjut aset yang dapat dioptimalkan pendayagunaannya. Perlu juga melakukan review pada rekomendasi solusi aset yang tidak dapat dioptimalkan. Highest and best use didefinisikan sebagai kegunaan yang paling layak, memungkinkan, dan sah dari tanah kosong atau tanah terbangun yang secara fisik memungkinkan, tepat didukung, layak secara finansial, dan yang menghasilkan nilai tertinggi dari tanah.

\section{- Pengawasan dan Pengendalian}

Pemerintah Daerah Kabupaten Kotawaringin Timur sudah menerapkan Simda (Sistem Informasi Manajemen Daerah) sebagai bentuk pengawasan dan pengendalian. Adapun saran dari penulis bahwasanya pengawasan perlu dilakukan pada tahap perencanaan yang termonitor sampai pada penghapusan aset. Dalam hal ini peran masyarakat, DPRD, auditor eksternal adalah Badan Pemeriksa Keuangan, auditor internal adalah Badan Pengawasan Keuangan dan Pembangunan serta inspektorat.

\section{Faktor Pendukung}

\section{- SDM Yang Memadai}

Bupati Kotawaringin Timur selaku kepala daerah sebagai pemegang kekuasaan pengelolaan barang milik daerah berwenang dan bertanggung jawab atas pembinaan dan pelaksanaan pengelolaan barang milik daerah, harus membuka diklat atau menggelar open class pelatihan pengelolaan aset daerah bekerja sama dengan balai diklat keuangan dan Badan Kepegawaian Pendidikan dan Pelatihan (BKPP) yang menghasilkan output berupa sertifikat.

\section{- Kebijakan}

Tentunya guna mendapatkan penetapan standarisasi harga satuan barang/jasa dan biaya harus di upgrade per tahunnya oleh Badan Pengelola Keuangan dan Aset Daerah. Diharapkan setiap OPD segera melakukan survei harga dan kemudian hasil survei yang disampaikan OPD ke BPKAD adalah harga dasar/harga konsumen.

\section{- Badan/lembaga}

Pemerintah Daerah Kabupaten Kotawaringin Timur membentuk BPKAD (Badan Pengelolaan Keuangan dan Aset 
Daerah) selaku pembantu pengelola barang milik daerah Kabupaten Kotawaringin Timur dan pengelola barang milik daerah yaitu Sekretariat Daerah serta OPD adalah selaku pengguna barang milik daerah.

\section{- Sistem Informasi}

Terdapat pengembangan sistem informasi yang transparan karena sudah berbasis web atau website yaitu Simda (Sistem Informasi Manajemen Daerah). Pengembangan sistem informasi ini berlabel Open Source jadi dapat di akses secara gratis dan legal. Selain itu, terdapat pengembangan sistem informasi yang transparan karena sudah berbasis web atau website yaitu Simda (Sistem Informasi Manajemen Daerah) yang bisa di akses di website sebagai berikut : simbada.kotimkab.go.id.

\section{- Budaya Masyarakat}

Badan Pengelola Keuangan dan Aset Daerah (BPKAD) akan memasukkan usulan program dan kegiatan yang diusulkan para pemangku kepentingan, baik dari kelompok masyarakat terkait langsung dengan pelayanan, LSM, asosiasi-asosiasi, perguruan tinggi maupun dari OPD Kabupaten.

\section{- Keuangan}

Saat ini pemerintah daerah membuat MOU dengan BPN untuk percepatan sertifikat aset tanah pemerintah daerah. Alasannya sekarang pemerintah daerah belum ada dana. Dengan keterbatasan dana di APBD tersebut yang membuat Pemerintah Daerah Kabupaten Kotawaringin Timur lambat dalam pelaksanaan proses kerja sama MOU.

\section{- Penelitian dan Pengembangan}

Kepala BPKAD sebagai pihak kesatu dan Kepala Kantor Pertanahan Kabupaten Kotawaringin Timur sebagai pihak kedua dengan membentuk tim inventarisasi dan persertifikatan barang milik daerah. Pemerintah daerah harus menyiapkan dukungan informasi dan dokumen dalam penanganan perkara, sengketa dan konflik tanah. Pastinya melakukan pengukuran dan pemetaan terhadap objek yang akan disertifikatkan dengan pemanfaatan Zona Nilai Tanah (ZNT). Para pihak kerja sama juga mempersiapkan dan menyediakan web service berbasis representational state transfer javascript object notation (REST JSON) untuk format pertukaran data di lingkungan mobile.

\section{Faktor Penghambat}

\section{- Aspek Fisik Belum Jelas}

Penyebabnya aspek fisik belum jelas adalah kelengkapan dokumen kepemilikan aset pemerintah daerah belum semuanya dilengkapi sesuai dengan ketentuan. Beberapa dokumen yang harus dilengkapi yaitu sertifikat, surat pernyataan tanah dan surat ketetapan Bupati.

\section{- Legalitas belum Jelas}

Faktor tingkat kepedulian terhadap peningkatan dokumen atau status kepemilikan dokumen tanah ini masih rendah. Karena pengurusan aset tanah ini memang tidak terlalu dianggap penting oleh OPD tertentu. Sampai saat ini realisasi dari MOU pemerintah daerah dan BPN belum ada hasil. Perjanjian tersebut baru dilaksanakan pada November 2019 dan belum ada alokasi dana dari pemerintah daerah kepada BPN.

\section{- Lemahnya Status Aset}

Sampai saat ini banyak konflik tanah antara pemerintah daerah dan masyarakat. Masyarakat dan pemerintah daerah samasama memiliki sertifikat dengan tanah yang sama pun ada. Adapun tanah tersebut menjadi bersengketa antara masyarakat dan pemerintah daerah. Solusi yang ditempuh pun sangat susah. Kecuali dengan jalan mediasi yang bersifat win win solution jadi tidak ada yang dirugikan. Adapun saran dari BPN dengan jalan peradilan jika gagal dalam mediasi. Peneliti menemukan permasalahan 
terkait aset lahan pemakaman umum jalan Jend. Sudirman Km. 6 s.d. 7 Kota Sampit.

\section{- Rendahnya Nilai Ekonomi Aset}

Letak dan kualitas dokumen akan berpengaruh terhadap nilai ekonomi aset. Rendahnya nilai ekonomi aset diketahui karna letak yang kurang strategis kemudian dokumen dari aset tersebut belum bersertifikat hal ini memengaruhi nilai aset.

\section{- Idle Asset}

Optimalisasi penggunaan dan pemanfaatan untuk meningkatkan pendapatan di mana aset berstatus sebagai idle capacity dapat dimanfaatkan sesuai peruntukan yang ditetapkan. Saran dari penulis dapat dilakukan highest and best use analysis dalam buku Siregar sehingga optimalisasi dari suatu aset yang berstatus idle capacity bisa didayagunakan.

\section{- KKN Pengelolaan Aset}

Pemerintah Daerah Kabupaten Kotawaringin Timur melalui Kejaksaan sudah banyak ditemukan contoh kasus dugaan korupsi yang menyeret mantan kepala Badan Pertanahan Nasional (BPN) Kabupaten Kotawaringin Timur. Penyidik kejaksaan Negeri Kabupaten Kotawaringin Timur kembali menemukan aset tersangka yang nilainya mencapai miliaran rupiah."Mulai dari rumah di perumahan PT Adhi Karya Property di jalan Tjilik Riwut, Kelurahan Baamang Barat dan rumah serta tanah kosong di kawasan Kelurahan Baamang Barat hingga rumah, barak dan gedung walet di kawasan Jalan Metro TV, Kelurahan Ketapang yang total nilainya mencapai miliaran rupiah." (http://www. borneonews.co.id)

Manajemen strategis yang perlu dilakukan pemerintah daerah dalam pengelolaan aset tanah dan bangunan Pemerintah Kabupaten Kotawaringin Timur sebagai berikut.

\section{Pengamatan Lingkungan}

\section{- Struktur}

Semua SOPD mempunyai pengurus barang masing-masing tetapi secara struktural penanganan aset termasuk tanah dan bangunan yang ada di Kabupaten Kotawaringin Timur berdasarkan regulasi yang mengendalikan adalah BPKAD pada bidang aset. Badan Pengelola Keuangan dan Aset Daerah merupakan OPD dengan tipe A yang melaksanakan fungsi penunjang keuangan sub fungsi pengelolaan keuangan dan aset daerah.

\section{- Budaya}

Pemerintah daerah melalui Badan Pengelola Keuangan dan Aset Daerah dalam hal ini selalu mengingatkan dan menghimbau melalui surat-surat resmi ke seluruh OPD untuk selalu mendokumentasikan terutama aset tetap tanah dan bangunan untuk dibuatkan dokumen tanahnya.

\section{- Sumber Daya Organisasi}

Sumber daya organisasi dalam upaya pencapaian optimalisasi kinerja pada pengelolaan aset daerah terbagi menjadi dua, yaitu Teknis dan Manusia. Hasil Wawancara dengan Suhartono, selaku Kepala Bidang Aset Daerah, pada 10 Maret 2020 pukul 10.15 WIB: "Secara umum bisa dikatakan sedang. Karena untuk yang di tingkat kecamatan masih kekuarangan SDM serta sarana dan prasarana penunjang pengelolaan aset." Saran dari penulis pada sarana penataan aset tanah pemerintah daerah dengan menggunakan drone. Tentunya pemerintah daerah harus memiliki tenaga teknis khusus pengguna drone di Badan Pengelolaan Keuangan dan Aset Daerah atau OPD lainnya.

\section{Perumusan Strategi}

Isu strategi Pemerintah Daerah Kabupaten Kotawaringin Timur melalui BPKAD dapat diidentifikasi sebagai berikut. 
1. Memenuhi amanat peraturan pemerintah No. 71 Tahun 2010 tentang Standar Akuntansi Pemerintahan serta aturan teknis yang dituangkan dalam Peraturan Menteri Dalam Negeri No. 64 Tahun 2013, maka pemerintah daerah harus menyusun Laporan keuangan daerah tahun 2019 dan seterusnya yang telah berbasis akrual. dalam penerapan SAP berbasis akrual terdapat beberapa potensi permasalahan antara lain:

1) Perbedaan akun anggaran dengan akun pertanggungjawaban yang masih harus dijembatani dengan konversi akun;

2) Perbedaan akun penatausahaan barang milik daerah dan akun pertanggungjawaban sehingga masih harus dijembatani dengan konversi akun;

3) Perlu adanya aturan teknis yang mengatur tentang penyusutanpenyusutan aset baik penyusutan pertama kali maupun penyusunan berkala;

4) Penyajian neraca pada saat penerapan akuntansi berbasis akrual masih belum disajikan sebagai nilai bersih, sebagai ilustrasi bahwa belum adanya penyusutan aset tetap sehingga belum dapat memberikan gambaran yang utuh terhadap penyajian laporan keuangan pemerintah daerah.

2. Seringnya terjadi perubahan regulasi tentang pengelolaan keuangan daerah, sehingga kurangnya koordinasi dan komunikasi antara OPD dapat memunculkan masalah tersendiri;

3. Penatausahaan, pengelolaan aset dan barang milik daerah belum berjalan optimal;

4. Sarana dan prasarana penunjang kegiatan di lingkup Pengelolaan aset daerah masih relatif terbatas, sementara intensitas kerja dan mobilitas personel sangat tinggi;

5. Belum terpenuhnya aspek legal yang jelas atas status, luas dan harga tanah dan/ atau bangunan guna penilaian aset pada aktiva tetap neraca daerah. Nilai aset yang dicantumkan dalam neraca masih merupakan nilai historis/nilai buku, sehingga masih diperlukan penilaian aset kembali untuk mendapatkan nilai pasar atas aset yang dimiliki pemerintah daerah.

\section{- Menentukan Misi}

Adapun misi Kabupaten Kotawaringin Timur pada RPJMD tahun 2016-2021. Berdasarkan misi tersebut di atas, maka Pemerintah Daerah Kabupaten Kotawaringin Timur melalui Badan pengelola Keuangan dan Aset Daerah mengacu kepada misi ke-3 (tiga) yaitu mewujudkan tata kelola pemerintahan yang efektif dan efisien.

\section{- Tujuan yang dapat dicapai}

Tujuan yang akan dicapai secara terukur, yaitu sesuatu yang akan dicapai/ dihasilkan secara nyata oleh Pemerintah Daerah Kabupaten Kotawaringin Timur melalui Badan Pengelola Keuangan dan Aset Daerah dalam jangka waktu 5 (lima) tahun mendatang, yaitu:

1. Meningkatkan kualitas laporan keuangan pemerintah daerah. Dalam hal ini menyangkut pada laporan keuangan OPD yang berkualitas mendukung Opini BPK RI.

2. Meningkatkan tertib dan akurasi data aset daerah yang sesuai dengan pemanfaatan dan peruntukannya.

\section{- Pengembangan Strategi}

RPJMD yang telah ditetapkan tidak terlepas dari tugas pokok dan fungsi Badan Pengelola Keuangan dan Aset Daerah, maka indikator kinerja dan target yang akan dicapai dalam kurun waktu lima tahun (2016-2021) berikut. 
1. Optimalisasi pengelolaan aset daerah melalui kajian evaluasi aset-aset daerah;

2. Memperbaiki manajemen aset, perbaikan kinerja pengelolaan aset dan peningkatan kapasitas pengelolaan aset;

3. Optimalisasi tugas dan mencapai Opini WTP melalui peningkatan komitmen pimpinan daerah dan seluruh aparat Pemerintah Kabupaten Kotawaringin Timur

4. Mempercepat penyelesaian tindak lanjut LHP dan action plan terhadap temuan permasalahan aset daerah;

5. Meningkatkan kualitas SDM dan kelembagaan, memperkuat regulasi daerah dalam mencapai Opini WTP.

\section{- Penetapan Pedoman Kebijakan}

Rumusan arah kebijakan Pemerintah Daerah Kabupaten Kotawaringin Timur melalui Badan Pengelola Keuangan dan Aset Daerah sebagai berikut.

1. Penerapan penyusunan laporan barang milik daerah pemerintah daerah sesuai jadwal dan Standar Akuntansi Pemerintah (SAP);

2. Penerapan penyusunan penganggaran sesuai dengan dokumen perencanaan, analisis standar satuan harga barang/jasa;

3. Terselenggaranya pemerintah daerah yang baik dan bersih serta bebas dari korupsi, kolusi dan nepotisme yang merupakan reformasi untuk meningkatkan kepercayaan publik terhadap pemerintah melalui transparansi pengelolaan aset daerah;

4. Optimalisasi sistem penggunaan teknologi informasi pada pengelolaan aset pemerintah daerah yang dimutakhirkan dan terintegrasi;

5. Sistem kerja yang profesional dengan didukung oleh sarana, prasarana dan SDM yang berkualitas untuk optimalisasi tata kelola aset daerah yang baik;
6. Profesional, transparan dan akuntabel dalam penatausahaan aset daerah;

7. Mengupayakan terwujudnya sistem dan prosedur pengelolaan aset daerah berdasarkan peraturan perundangundangan yang bertumpu pada kepentingan masyarakat yang didukung oleh sarana prasarana dan SDM yang berkualitas.

\section{Implementasi Strategi}

\section{- Pengembangan Program}

Berdasarkan wawancara dengan Suhartono, selaku Kepala Bidang Aset Daerah, pada 10 Maret 2020 pukul 10.00 WIB pengembangan program Badan Pengelola Keuangan dan Aset Daerah (BPKAD) dengan melaksanakan rapat-rapat koordinasi dengan OPD untuk melakukan sinkronisasi terkait dengan aset dan pula melakukan program bimbingan teknis dengan menyampaikan informasi apa yang harus OPD tersebut lakukan melalui rapat-rapat koordinasi. Kemudian Badan Pengelola Keuangan dan Aset Daerah (BPKAD) melakukan program kegiatan inventarisasi secara rutin untuk melakukan penataan aset daerah pada OPD. pencatatan harus segera dilaksanakan di Kartu Inventarisasi Barang (KIB) A untuk aset tanah atau Kartu Inventarisasi Barang (KIB) C untuk aset gedung dan bangunan OPD tersebut.

Adapun saran dari penulis untuk pengelolaan aset yang lebih baik pemerintah daerah perlu menganggarkan dana pada sistem informasi barang milik daerah berupa program INTIP (Inventarisasi Tanah Instansi Pemerintah), cloud computing dan big data, pemutakhiran teknologi informasi aset pemerintah daerah khususnya aset tanah dan bangunan dengan menyesuaikan era revolusi industri 4.0. 
Tabel 2 Realisasi Anggaran Per Program Per Kegiatan pada Aset Daerah tahun 2018

\begin{tabular}{|c|c|c|c|c|}
\hline No. & Uraian & Pagu Anggaran (Rp) & Realisasi (Rp) & $\begin{array}{l}\text { Persentase } \\
\quad(\%)\end{array}$ \\
\hline 1. & $\begin{array}{l}\text { Pengamanan aset barang } \\
\text { milik daerah }\end{array}$ & $160.400 .000,00$ & $149.945 .000,00$ & $93,48 \%$ \\
\hline 2. & $\begin{array}{l}\text { Singkronasi tabel nomor } \\
\text { kode barang dan kode lokasi } \\
\text { barang }\end{array}$ & $119.062 .500,00$ & $109.018 .000,00$ & $91,56 \%$ \\
\hline 3. & Lelang Aset Daaerah & $139.700 .000,00$ & $134.850 .000,00$ & $96,53 \%$ \\
\hline 4. & $\begin{array}{l}\text { Rekonsiliasi Aset Barang Milik } \\
\text { Daerah }\end{array}$ & $126.685 .000,00$ & $108.149 .000,00$ & $85,37 \%$ \\
\hline 5. & $\begin{array}{l}\text { Pembuatan Buku Inventaris } \\
\text { Barang }\end{array}$ & $64.625 .000,00$ & $58.748 .000,00$ & $90,91 \%$ \\
\hline 6. & $\begin{array}{l}\text { Penyusunan Rencana } \\
\text { Kebutuhan dan Rencana } \\
\text { Kebutuhan Pemeliharaan } \\
\text { Barang Milik Daerah }\end{array}$ & $39.340 .000,00$ & $35.093 .000,00$ & $89,20 \%$ \\
\hline 7. & Penataan Barang Milik Daerah & $190.370 .000,00$ & $187.958 .000,00$ & $98,55 \%$ \\
\hline 8. & $\begin{array}{l}\text { Invenntarisasi Barang Milik } \\
\text { Daerah }\end{array}$ & $147.050 .000,00$ & $116.505 .000,00$ & $79,23 \%$ \\
\hline 9. & $\begin{array}{l}\text { Sistem Informasi Barang Milik } \\
\text { Daerah }\end{array}$ & $722.445 .000,00$ & $694.079 .152,00$ & $96,07 \%$ \\
\hline 10. & $\begin{array}{l}\text { Penataan Aset Daerah } \\
\text { Berbasis Spasial }\end{array}$ & $58.700 .000,00$ & $57.970 .000,00$ & $98,76 \%$ \\
\hline 11. & Penyusunan Standar Harga & $513.390 .000,00$ & $501.629 .200,00$ & $97,71 \%$ \\
\hline 12. & $\begin{array}{l}\text { Sosialisasi Peraturan } \\
\text { Pengelolaan Barang Milik } \\
\text { Daerah }\end{array}$ & $109.840 .000,00$ & $104.974 .500,00$ & $95,57 \%$ \\
\hline 13. & $\begin{array}{l}\text { Rapat-rapat koordinasi dan } \\
\text { konsultasi dalam daerah }\end{array}$ & $1.303 .760 .000,00$ & $1.299 .438 .933,00$ & $99,67 \%$ \\
\hline 14. & $\begin{array}{l}\text { Rapat-rapat koordinasi dan } \\
\text { konsultasi ke luar daerah }\end{array}$ & $495.080 .000,00$ & $482.201 .094,00$ & $97,40 \%$ \\
\hline 15. & $\begin{array}{l}\text { Pendidikan dan Pelatihan } \\
\text { Formal }\end{array}$ & $431.125 .000,00$ & $296.539 .518,00$ & $91,98 \%$ \\
\hline
\end{tabular}

Sumber: Laporan Kinerja Instansi Pemerintah (LKIP) BPKAD tahun 2018 


\section{- Anggaran}

Berdasarkan wawancara dengan Suhartono, selaku Kepala Bidang Aset Daerah, pada 10 Maret 2020 pukul 10.00 WIB untuk penentuan kebutuhan anggaran, kuasa pengguna barang harus menyerahkan RKBMD (Rencana Kebutuhan Barang Milik Daerah) sebelum anggaran tersebut ditetapkan atau dibahas. Jadi, OPD menyerahkan rencana kebutuhan barang yang diperlukan sesuai dengan perencanaan untuk dialokasikan anggarannya, kalau tidak ada RKBU maka tidak bisa dibahas dalam kebutuhan barang mereka melalui dana APBD. Belum bisa dikatakan $100 \%$ pada proses penganggaran karna pemerintah daerah belum menerbitkan standar kebutuhan barang. Seharusnya selain standar harga perlu adanya standar kebutuhan barang OPD. pemerintah daerah punya peraturan bupati tentang standarisasi sarana dan prasarana yang saat ini tidak relevan lagi dikarenakan berdasarkan Permendagri yang sudah lama.
Dalam menjalankan kegiatan operasional Pemerintah Kabupaten Kotawaringin Timur melalui Badan Pengelola Keuangan dan Aset Daerah ditunjang dengan Anggaran Belanja Tidak Langsung sebesar Rp5.640.531.925,00 dan Belanja Langsung sebesar Rp16.401.404.250,00 pada 2018. Badan Pengelolaan Keuangan dan Aset Daerah telah menganggarkan untuk membiayai seluruh program dan kegiatan sebesar Rp22.041.936.175,00 dengan realisasi penyerapan anggaran sebesar Rp19.923.703.319, 58 atau capaian keuangan sebesar 90, $39 \%$.

\section{- Prosedur}

Dalam rangka mewujudkan manajemen pemerintahan yang efektif, transparan, dan akuntabel serta berorientasi pada hasil. Prosedur sasaran kegiatan yang dilakukan oleh Kepala Bidang Aset daerah Suhartono, A.KS bersama Kepala Sub Bidang Perencanaan Dan Penggunausahaan Aset Daerah H. Syahri Fazrin sebagaimana tampak pada Tabel 3 dan 4 .

Tabel 3 Sasaran Kegiatan Badan Pengelola Keuangan dan Aset Daerah pada Sub Bidang Pengamanan dan Pengendalian Aset Daerah

\begin{tabular}{|c|c|c|c|c|}
\hline No & Sasaran Kegiatan & Indikator Kegiatan & Target & $\begin{array}{c}\text { Jumlah Anggaran } \\
\text { (Rp) }\end{array}$ \\
\hline 1. & $\begin{array}{l}\text { Terdatanya aset tanah milik } \\
\text { Pemerintah daerah secara } \\
\text { hokum }\end{array}$ & $\begin{array}{l}\text { Jumlah aset tanah milik } \\
\text { pemerintah daerah yang terdata } \\
\text { secara hukum }\end{array}$ & 3 persil & $150.000 .000,00$ \\
\hline 2. & $\begin{array}{l}\text { Tercatatnya aset sesuai } \\
\text { dengan tabel kode barang } \\
\text { dan kode lokasi barang }\end{array}$ & $\begin{array}{l}\text { Jumlah aset yang tercatat pada } \\
\text { tabel nomor kode barang dan } \\
\text { kode lokasi barang }\end{array}$ & 300 buah & $89.180 .000,00$ \\
\hline 3. & $\begin{array}{l}\text { Terlaksananya lelang aset } \\
\text { pemda yang sudah tidak } \\
\text { digunakan }\end{array}$ & Jumlah aset pemda yang di lelang & 75 Buah & $131.700 .000,00$ \\
\hline 4. & $\begin{array}{l}\text { Terlaksananya rekonsiliasi } \\
\text { barang milik daerah }\end{array}$ & $\begin{array}{l}\text { Jumlah SOPD yang melakukan } \\
\text { rekonsiliasi barang milik daerah }\end{array}$ & 50 SOPD & $111.310 .000,00$ \\
\hline 5. & $\begin{array}{l}\text { T e r l a k s a n a n y a } \\
\text { inventarisasi aset pada } \\
\text { SOPD }\end{array}$ & $\begin{array}{l}\text { Jumlah SOPD yang dilakukan } \\
\text { pendampingan inventarisasi aset }\end{array}$ & 50 SOPD & $113.550 .000,00$ \\
\hline
\end{tabular}

Sumber: Laporan Kinerja Instansi Pemerintah (LKIP) BPKAD tahun 2018 
Tabel 4 Sasaran Kegiatan Badan Pengelola Keuangan dan Aset Daerah pada Sub Bidang Penatausahaan dan Informasi Aset

\begin{tabular}{|c|c|c|c|c|}
\hline No & Sasaran Kegiatan & Indikator Kegiatan & Target & $\begin{array}{c}\text { Jumlah } \\
\text { Anggaran (Rp) }\end{array}$ \\
\hline 1. & $\begin{array}{l}\text { Tersedianya buku HSBJ } \\
\text { Kabupaten Kotim }\end{array}$ & $\begin{array}{l}\text { Jumlah buku harga standard } \\
\text { barang/jasa }\end{array}$ & 2 buah & $369.170 .000,00$ \\
\hline 2. & $\begin{array}{l}\text { Terlaksananya Perda } \\
\text { pengelolaan barang milik } \\
\text { daerah }\end{array}$ & $\begin{array}{l}\text { Jumlah peserta yang mengikuti } \\
\text { sosialisasi Perda pengelolaan } \\
\text { barang milik daerah }\end{array}$ & 100 orang & $37.700 .000,00$ \\
\hline 3. & $\begin{array}{l}\text { Terlaksananya sistem } \\
\text { pengelolaan barang milik } \\
\text { daerah }\end{array}$ & $\begin{array}{l}\text { Jumlah peserta yang mengikuti } \\
\text { pendampingan } \\
\text { pengelolaan barang milik daerah }\end{array}$ & 150 orang & $332.975 .000,00$ \\
\hline 4. & $\begin{array}{l}\text { Tersedianya peta lokasi aset } \\
\text { di Kabupaten Kotim }\end{array}$ & $\begin{array}{l}\text { Jumlah lokasi aset daerah } \\
\text { berbasis spesial }\end{array}$ & $2 \mathrm{Kec}$ & $58.700 .000,00$ \\
\hline
\end{tabular}

Sumber: Laporan Kinerja Instansi Pemerintah (LKIP) BPKAD tahun 2018

\section{Evaluasi dan Pengendalian}

\section{- Data Kinerja}

Tim yang dibentuk akan memantau dalam bulan tertentu atau pada satu tahun penanganan apa yang dilakukan OPD pada aset tanah dan bangunan kemudian dilaporkan ke BPK. Contoh laporan sertifikat dan laporan dokumen kepemilikan OPD masing-masing berapa yang sudah dan berapa yang belum dengan melakukan labeling. Badan Pengelola Keuangan dan Aset Daerah membentuk tim monitoring untuk mengawasi hasil kerja yang dilakukan OPD terhadap perkembangan dan kemajuan input barang pada Sistem Informasi Manajemen Daerah (SIMDA).

\section{- Laporan Aktivitas}

Contoh laporan hasil inventarisasi berita acara dari bangunan baik menjadi bangunan rusak. Kemudian dasar berita acara ini dijadikan bahan untuk input merubah kondisi barang dari bangunan baik menjadi bangunan rusak (dari aset tetap ke aset lainnya).

\section{SIMPULAN}

1. Pelaksanaan pengelolaan aset tanah dan bangunan: (a) Inventarisasi aset masih belum baik. Terdapat pengurus barang yang belum paham; (b) Legal audit sudah cukup baik dengan menjalin kerja sama dengan BPN dan KPKNL; (c) Penilaian aset. Cukup baik dengan review hasil inventarisasi aset, Inspeksi, penetapan nilai sesuai kelompok aset dan catatan aset tidak dapat dinilai serta aset potensial; (d) Optimalisasi aset masih belum baik; (e) Pengawasan dan pengendalian dengan menerapkan Simbada yang sampai saat ini bekerja dengan baik.

2. Faktor pendukung: (a) SDM yang memadai pada bidang aset BPKAD dan pengurus barang masing-masing OPD. (b) Adanya kebijakan dalam rangka menciptakan tertib administrasi pengelolaan barang milik daerah. (c) Adanya BPKAD (Badan Pengelolaan Keuangan dan Aset Daerah) selaku pembantu pengelola barang milik daerah Kabupaten Kotawaringin Timur. (d) Terdapat pengembangan sistem informasi yang transparan karena sudah berbasis web atau website yaitu Simda (Sistem Informasi Manajemen Daerah). (e) Badan Pengelola Keuangan dan Aset Daerah (BPKAD) akan memasukkan usulan program dan kegiatan yang 
diusulkan para pemangku kepentingan. (f) Pada pembahasan APBD tahun 2020 DPRD meminta kepada pemerintah daerah bagian aset BPKAD untuk mendata aset-aset Pemerintah Daerah Kabupaten Kotawaringin Timur yang belum memiliki legalitas. (g) Adapun terobosan pengembangan dari Pemerintah daerah yaitu percepatan inventarisasi dan penyertifikatan barang milik daerah berupa tanah. Sedangkan, Faktor penghambat: (a) Aspek Fisik belum jelas. (b) Legalitas belum jelas. (c) Lemahnya status aset. (d) Rendahnya nilai ekonomi aset. (e) Banyak aset tanah dan bangunan yang merupakan idle asset atau belum termanfaatkan. (f) KKN Pengelolaan Aset. Pemerintah Daerah Kabupaten Kotawaringin Timur melalui Kejaksaan sudah banyak ditemukan contoh kasus dugaan korupsi.

3. Manajemen strategis yang perlu dilakukan pemerintah daerah dalam pengelolaan aset tanah dan bangunan Pemerintah Kabupaten Kotawaringin Timur.

a. Pengamatan Lingkungan di antaranya : (a) Struktur pemerintah daerah dalam pengelolaan aset daerah sudah cukup memadai. (b) Budaya birokrasi atau budaya aparatur konsisten dengan tujuan, strategi, kebijakan, dan programprogram pemerintah daerah guna mendukung pengelolaan aset. (c) Sumber daya organisasi. Secara umum bisa dikatakan sedang, Karna untuk yang di tingkat kecamatan masih kekuarangan SDM serta sarana dan prasarana penunjang pengelolaan aset.

b. Perumusan strategi: (a) Menentukan Misi yaitu mewujudkan tata kelola pemerintahan yang efektif dan efisien. (b) Tujuan yang dapat dicapai, Meningkatkan kualitas laporan keuangan pemerintah daerah untuk mendukung, meningkatkan tertib dan akurasi data aset daerah yang sesuai dengan pemanfaatan dan peruntukannya. (c) Pengembangan Strategi, yaitu Terwujudnya laporan aset OPD yang baik dan benar sesuai dengan peraturan perundang-undangan yang berlaku. (d) Penetapan pedoman kebijakan, Penerapan penyusunan laporan barang milik daerah pemerintah daerah sesuai jadwal dan Standar Akuntansi Pemerintah (SAP);

c. implementasi strategi: (a) Pengembangan program, menyertakan program dan kegiatan dalam mendukung meningkatkan tertib dan akurasi data aset daerah yang sesuai dengan pemanfaatan dan peruntukannya. (b) Anggaran, pada perencanaan kebutuhan aset yang digunakan sebagai rujukan untuk anggaran per program dan per kegiatan pada aset daerah sudah sesuai dengan aturan dan sesuai dengan kebutuhan. (c) Prosedur, Prosedur sasaran kegiatan yang dilakukan oleh Kepala Bidang Aset daerah sudah cukup baik dalam rangka mewujudkan manajemen pemerintahan yang efektif, transparan, dan akuntabel serta berorientasi pada hasil.

d. evaluasi dan pengendalian: (a) Data kinerja, pada evaluasi dan pengendalian berupa data kinerja sudah cukup baik dengan adanya tim monitoring hasil kerja yang dilaksanakan oleh OPD. (b) Laporan aktivitas, Terdapat dasar berita acara yang menjadi laporan aktivitas OPD pada pengelolaan aset daerah yang kemudian dilaporkan ke Badan Pengelola Keuangan dan Aset Daerah dan OPD terkait. 


\section{SARAN}

Pengelolaan aset tanah dan bangunan Kabupaten Kotawaringin Timur meliputi: (a) Inventarisasi Aset. Adapun saran dari penulis untuk pemerintah daerah melalui Badan Pengelolaan Keuangan dan Aset Daerah agar terjalin komunikasi yang intensif dengan aplikasi Zoom. (b) Legal audit. Pemerintah daerah terus menjalin kerja sama dengan instansi vertikal untuk pengamanan aset daerah. (c) Penilaian aset. Pemerintah daerah perlu melakukan outsourcing kepada konsultan penilai yang profesional dan independen. (d) Optimalisasi aset. Pemerintah daerah harus melakukan review daftar aset potensial dengan analisis highest and best use aset potensial. (e) Pengawasan dan pengendalian.

Adapun saran dari penulis bahwasanya pengawasan perlu dilakukan pada tahap perencanaan yang termonitor sampai pada penghapusan aset. Masyarakat, DPRD, auditor eksternal adalah Badan Pemeriksa Keuangan, auditor internal adalah Badan Pengawasan Keuangan dan Pembangunan serta inspektorat sangat berpengaruh pada pengawasan.

\section{DAFTAR RUJUKAN}

Arikunto, Suharsimi. 2010. Prosedur Penelitian. Rineka Cipta. Jakarta.

Bungin, Burhan. 2009. Penelitian Kualitatif. Kencana. Jakarta.

Creswell, John W. 2016. Research Design: Pendekatan Metode Kualitatif, Kuantitatif dan Campuran. Edisi Keempat. Pustaka Pelajar. Yogyakarta.

David, Fred R dan Forest R. David. 2016. Manajemen Strategis: Suatu Pendekatan Keunggulan Bersaing. Penerjemah Novita P. dan Liza Nurbani P. Salemba Empat. Jakarta.

Effendy, Khasan. 2010. Memadukan Metode Kuantitatif Kualitatif. Prahasta. Bandung.

Hunger, J. David dan Thomas L. Wheelen. 2003. Manajemen Strategis. Andi. Penerjemah: Julianto Agung. Yogyakarta.
Moleong, Lexy J. 2011.Metodologi Penelitian Kualitatif, Remaja Rosdakarya. Bandung.

Muhammad, Suwarsono. 2013. Manajemen Strategis Konsep dan Alat Analisis. Unit Penerbit dan Percetakan. Yogyakarta.

Ndraha, Taliziduhu. 2011. Kybernologi (Sebuah Rekonstruksi Ilmu Pemerintahan). Rineka Cipta. Jakarta.

Nawawi, H. Hadari. 2012. Manajemen Strategis OrganisasiNonprofitBidangPemerintahan. Gajah Mada University. Yogyakarta.

Pearce, John A. dan Richard B. Robinson. 2014. Manajemen Strategis: Formulasi, Implementasi, dan Pengendalian. Salemba Empat. Penerjemah: Nia Pramita. Jakarta.

Prawirosentono, Suyadi dan Dewi Primasari. 2014. Manajemen Strategis dan Pengambilan Keputusan Korporasi. PT Bumi Aksara. Jakarta.

Siregar, D. Doli. 2004. Manajemen Aset. Gramedia Pustaka Utama Jakarta.

Soleh, Chobib dan Rochmansjah, Heru. 2010. Pengelolaan Keuangan dan Aset Daerah, Fokusmedia. Bandung.

Simangunsong, Fernandes, 2016, Metodologi Penelitian Pemerintahan. Alfabeta. Bandung.

Silalahi, Uber. 2010. Metode Penelitian Sosial. Refika Aditama. Bandung.

Suwanda, Dadang. 2015. Optimalisasi Pengelolaan Aset Pemda. PPM. Jakarta.

Sinurat, Marja. 2018. Akuntansi Keuangan Daerah. Ghalia indonesia. Bogor.

Soegartono, Irawan. 2011. Metode penelitian Sosial: Suatu Teknik Penelitian Bidang Kesejahteraan Sosial dan Ilmu Sosial Lainnya. PT Remaja Rosdakarya. Bandung.

Wasistiono, Sadu dan Fernandes Simangunsong. 2015. Metodologi Ilmu Pemerintahan. IPDN Press. Jatinangor.

Jurnal

Adhi, Soewanto. 2016. Optimalisasi Pemanfaatan Aset Daerah Sebagai Sumber PAD Di Dinas Pengelolaan Keuangan Dan Aset Daerah Kota Semarang Tahun 2013 - 2015. Jurnal Ilmiah Ilmu Pemerintahan. Maret 2016. Vol 2. No. 1. 
Antoh, Agustina Ester, 2017, "Pengaruh Manajemen Aset dalam Optimalisasi Aset Tetap (Tanah dan Bangunan) Pemerintah Daerah (Studi di Kabupaten Paniai)". Jurusan Manajemen, Fakultas Ekonomi \& Bisnis, Universitas Cendrawasih (Jurnal). JULI 2017 (ISSN 2615 - 0425).

Gaffar, Ismail, Basri Hasanuddin, dan Andi Kusumawati. 2017. Pengaruh Inventarisasi Aset, Sumber Daya Manusia terhadap Optimalisasi Aset Dengan Sistem Informasi Sebagai Variabel Moderasi. Jurnal Analisis. Desember 2017. Vol. 6 No. 2. ISSN 2303-100X.

Kurniyanta, Aan, Ahmad Roziq, dan R. Andi Sularso. 2018. Analisis Pengaruh Manajemen Aset, Sistem Pengendalian Internal Pemerintah Dan Kompetensi Sumber Daya Manusia terhadap Pendapatan Dengan Optimalisasi Aset Idle Sebagai Variabel Intervening (Studi Kasus Pada Satuan Kerja Kpknl Jember). Jurnal Bisnis dan Manajemen. Januari 2018. Vol. 12, No. 1.

Pratama, Muhammad Rizky, 2016. Pengaruh Manajemen Aset Terhadap Optimalisasi Pengelolaan Aset Daerah, Jurnal Akuntansi \& Keuangan Daerah. Volume 11, No. 2, November 2016.

\section{Peraturan Perundang-Undangan}

Peraturan Pemerintah No. 27 Tahun 2014 tentang Pengelolaan Barang Milik Negara atau Daerah

Peraturan Menteri Dalam Negeri No. 17 Tahun 2007 tentang Pedoman Teknis Pengelolaan Barang Milik Daerah

Peraturan Menteri Dalam Negeri No. 19 Tahun 2016 tentang Pedoman Pengelolaan Barang Milik Daerah

Peraturan Daerah Kabupaten Kotawaringin Timur No. 9 tahun 2016 tentang pembentukan dan Susunan Perangkat Daerah Kabupaten Kotawaringin Timur

\section{Hasil Penelitian Sebelumnya}

Krisindarto, Agung, 2012 "Pengelolaan Aset Tanah Milik Pemerintah Kota Serang". Jurnal Pembangunan Wilayah dan Kota.
Volume 8 (4): 403-411 Desember 2012, Biro Penerbit Planologi Undip (Jurnal).

Wanisa, Zahra, 2016 "Kinerja Pegawai Dinas Pengelolaan Bangunan Dan Tanah dalam Pelaksanaan Inventarisasi Aset Tanah di Kota Surabaya". Kebijakan dan Manajemen Publik, Volume 4, No. 2, MeiAgustus 2016, Universitas Airlangga (ISSN 2303-341X) (Jurnal).

Antoh, Agustina Ester, 2017, "Pengaruh Manajemen Aset dalam Optimalisasi Aset Tetap (Tanah dan Bangunan) Pemerintah Daerah (Studi di Kabupaten Paniai)". Jurusan Manajemen, Fakultas Ekonomi \& Bisnis, Universitas Cendrawasih. JULI 2017 (ISSN 2615 - 0425). (Jurnal)

Parwata, I Ketut Gede Candra, 2016, “Optimalisasi pengelolaan aset tanah pemerintah Provinsi Bali dalam upaya meningkatkan pendapatan asli daerah (PAD)". Jurusan Manajemen Administrasi Pemerintah Daerah (Jurnal).

Jamaludin, 2017, "Pengaruh Inventarisasi Aset, Legal Audit Aset, dan Penilaian Aset terhadap Optimalisasi Pemanfaatan Aset Tetap (Tanah dan Bangunan) Milik Pemerintah Provinsi NTB". Manajemen Keuangan (Jurnal).

Jusmin dan Nursalim, 2018 "Pengaruh Manajemen Aset terhadap Tingkat Optimalitas Aset Tetap (Tanah Dan Bangunan) Pemerintah Kabupaten Sorong". STKIP Muhammadiyah Sorong (Jurnal).

\section{Berita Surat Kabar}

Radar Sampit, Jumat, 29 Maret 2019

Kalteng Pos, senin, 8 April 2019

Kalteng Pos, Rabu 12 Februari 2020

\section{Website}

http: / / info-kalimantantengah.blogspot. com /2011/06/profil-kabupatenkotawaringin-timur.html

Aplikasi ZOOM : Perannya di Dunia Pendidikan - depoedu.com https://www.google. com $/ \mathrm{m} ? \mathrm{q}=$ manfaat + daring + dengan + aplikasi + zoom \& client $=$ ms - opera mobile\&channel=new\&espv=1 (diakses pada 06 juni 2020)

https://bappenda.kotimkab.go.id/dashboard/ 